\title{
Disinfectant testing against human norovirus surrogates-What infection preventionists need to know
}

\author{
James S. Clayton $\mathrm{BSc}^{1}$, Hannah K. Bolinger $\mathrm{PhD}^{1}$ and Lee-Ann Jaykus $\mathrm{PhD}^{2}$ \\ ${ }^{1} \mathrm{PDI}$, Montvale, New Jersey and ${ }^{2}$ North Carolina State University, Raleigh, North Carolina
}

To the Editor-Human norovirus is the leading cause of acute viral gastroenteritis worldwide, and it is the greatest contributor to foodborne illness. The illness affects millions of people every year, as well as many restaurants, schools, and healthcare establishments, among others. ${ }^{1,2}$ Symptoms include nausea, vomiting, and diarrhea and usually last 2-3 days. The virus is transmitted by direct routes (person-to-person most commonly), or indirectly (via contaminated surfaces or contaminated food and water). ${ }^{3}$ Viruses are typically studied and quantified using cell-culturebased infectivity assays, a model in which viruses are propagated in the laboratory in vitro. However, until very recently, such a system did not exist for human norovirus. ${ }^{4}$ In its absence, molecular-based techniques such as real-time polymerase chain reaction (RT-PCR) have been used to quantify reductions in norovirus. However, these techniques cannot differentiate between infectious and noninfectious virus, so they have limited utility in disinfection studies. ${ }^{5}$ Due to the issues with culturing and quantifying human norovirus, the US Environmental Protection Agency (EPA) has turned to the use of culturable norovirus surrogates for petitioning label claims.

The EPA currently only allows virucidal claims against human norovirus to be made from data that demonstrate a disinfectant's efficacy against feline calicivirus $(\mathrm{FCV})^{6}$. Despite this, there are EPA-registered products that cite efficacy against murine norovirus (MNV) as the basis for their antinoroviral claims. The problem with these surrogates is that their response to sanitizers and disinfectants may not reflect the true behavior of human norovirus, a problem that the CDC recognizes for feline calicivirus. ${ }^{7}$ For example, it is well documented that FCV is readily inactivated at low and high $\mathrm{pH}$. However, human norovirus must survive the highly acidic gastrointestinal tract to infect its host, so it is much more resistant to low $\mathrm{pH}$ (ie, acid environment) than is $\mathrm{FCV}^{8}$ As FCV is the only EPA-accepted surrogate, ${ }^{6}$ manufacturers of disinfectants have no choice but to use it as the basis for claims of antinoroviral activity. Even replacing FCV with $\mathrm{MNV}$ is not advisable because data have shown MNV to be more susceptible to alcohols than FCV, ${ }^{8,9}$ and based on PCR assays, many human norovirus strains appear to be more resistant to alcohols than MNV. ${ }^{8,9}$ In short, whether the surrogate is FCV or $\mathrm{MNV}$, there are documented instances in which inactivation of norovirus surrogates with a sanitizer or disinfectant does not translate to equal efficacy against human norovirus. When this occurs, human norovirus is almost always the more resistant.

A third surrogate has recently begun appearing in the literature that shows less susceptibility to alcohols and/or $\mathrm{pH}$ extremes. Tulane virus is another member of the Caliciviridae family, to

Author for correspondence: James S. Clayton, 100 Philips Parkway, Montvale NJ, 07645-1800. E-mail:James.Clayton@pdipdi.com

Cite this article: Clayton JS, Bolinger HK, Jaykus LA (2018). Disinfectant testing against human norovirus surrogates-What infection preventionists need to know. Infection Control \& Hospital Epidemiology 2018 2018, 39, 1388-1389. doi: 10.1017/ ice. 2018.210 which human norovirus belongs, and shares many important features with its norovirus cousins. ${ }^{10}$ For example, Tulane virus is the only human norovirus surrogate that binds histo-blood group antigens, which are believed to be the norovirus host cell receptor. The ability of Tulane virus to bind these antigens is likely due to the similarity between its capsid and that of human norovirus. ${ }^{10}$ Similarities in the capsid protein are important because disruption of this protein is usually a critical aspect of inactivation by disinfectants. ${ }^{10}$ Because evidence is mounting regarding the behavior of Tulane virus in disinfection studies, it should be considered by regulatory agencies as a justifiable surrogate for human norovirus.

As the new human norovirus culture technique improves and is used more widely, it should become feasible to test disinfectants against the real virus of concern. This would prevent the confusion associated with interpreting results from surrogates. Until that time, it is best to follow the guideline of the Centers for Disease Control and Prevention (CDC) to use a chlorine-bleach solution, ${ }^{7}$ which based on current data, is the most effective disinfectant against human norovirus. ${ }^{8}$ As the regulatory landscape continues to evolve, it is important for health practitioners to be cognizant of potential limitations of surrogates, specifically their differential behavior compared to one another and to human norovirus, even those recognized by the EPA. Public health, not regulatory compliance, should form the cornerstone of infection control. As practitioners, let us be cognizant of the scientific limitations in our current regulatory system and always choose what is right for health.

\section{Acknowledgments}

Financial support. No financial support was provided relevant to this article.

Conflicts of interest. All authors report no conflicts of interest relevant to this article.

\section{References}

1. Barclay L, Park GW, Vega E, et al. Infection control for norovirus. Clin Microbiol Infect 2014;20:731-740.

2. Scallan E, Hoekstra RM, Angulo FJ, et al. Foodborne illness acquired in the United States—major pathogens. Emerg Infect Dis 2011;17:7-15.

3. Kambhampati A., Koopmans M, Lopman BA. Burden of norovirus in healthcare facilities and strategies for outbreak control. J Hosp Infect 2015;89:296-301.

4. Ettayebi K, Crawford SE, Murakami K, et al. Replication of human noroviruses in stem cell-derived human enteroids. Science 2016;353:1387-1393.

5. Lamhoujeb S, Fliss I, Ngazoa SE, Jean J. Evaluation of the persistence of infectious human noroviruses on food surfaces by using real-time nucleic acid sequence-based amplification. Appl Environ Microbiol 2008;74: 3349-3355.

6. EPA product performance guidelines. Regulations.gov website. https:// www.regulations.gov/document?D=EPA-HQ-OPPT-2009-0150-0034. Published 2018. Accessed 22 May, 2018. 
7. Preventing norovirus infection. Centers for Disease Control and Prevention website. https://www.cdc.gov/norovirus/about/prevention.html. Published 2018. Accessed 19 July, 2018.

8. Tung G, Macinga D, Arbogast J, Jaykus L. Efficacy of commonly used disinfectants for inactivation of human noroviruses and their surrogates. J Food Prot 2013;76:1210-1217.
9. Cromeans T, Park GW, Costantini V, et al. Comprehensive comparison of cultivable norovirus surrogates in response to different inactivation and disinfection treatments. Appl Environ Microbiol 2014;80:5743-5751.

10. Kniel KE. The makings of a good human norovirus surrogate. Curr Opin Virol 2014;4:85-90.

\title{
Patients as stakeholders: Developing a patient-centered healthcare epidemiology research agenda
}

\author{
Julie A. Keating $\mathrm{PhD}^{1}$, Nicole Brys $\mathrm{MPH}^{1,2}$, Mary Jo Knobloch PhD, $\mathrm{MPH}^{1,2}$ and Nasia Safdar MD, $\mathrm{PhD}^{1,2}$ \\ ${ }^{1}$ William S. Middleton VA Hospital, Madison, Wisconsin and ${ }^{2}$ Division of Infectious Diseases, Department of Medicine, University of Wisconsin-Madison, Madison, \\ Wisconsin
}

To the Editor-Due to its many benefits, stakeholder engagement in health research has been increasingly prioritized in recent years. $^{1-9}$ Engagement throughout the research cycle, from idea development through dissemination of results, helps to ensure

Table 1. Patient-Perceived Implementation Barriers to HAI Prevention Strategies

\begin{tabular}{|c|c|c|}
\hline Prevention Strategies & Individual-Level Barriers & Provider- and Institutional-Level Barriers \\
\hline \multicolumn{3}{|c|}{ 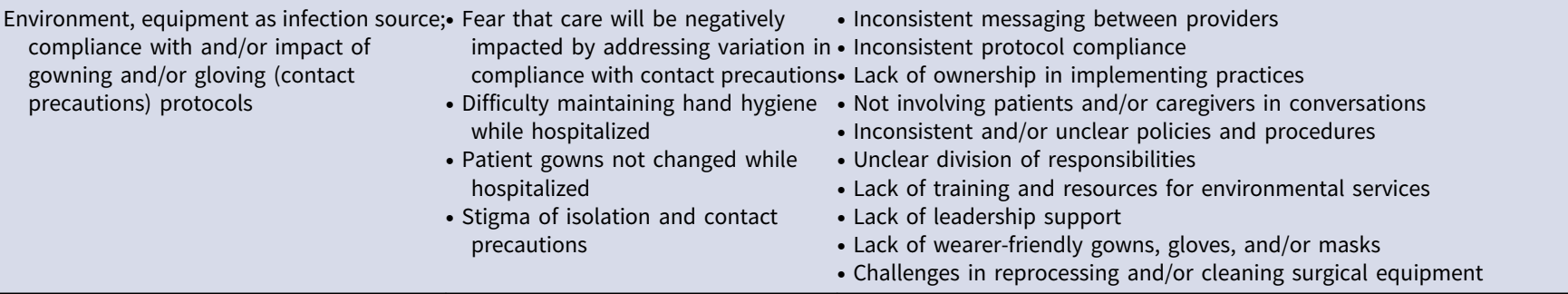 } \\
\hline $\begin{array}{l}\text { Presurgical preparation (CHG bathing, } \\
\text { Staphylococcus aureus testing, lifestyle } \\
\text { changes) }\end{array}$ & $\begin{array}{l}\text { - Lack of education about preparation } \\
\text { for surgery and the risks of not } \\
\text { preparing } \\
\text { - Variation in procedural information } \\
\text { - Variation in products and use } \\
\text { - Not preparing for surgery }\end{array}$ & $\begin{array}{l}\text { - Inconsistent messaging between providers } \\
\text { - Inconsistent provider involvement } \\
\text { - Lack of access and/or encouragement to learn best practices } \\
\text { - Variation in evidence for and priority of practices } \\
\text { - Variation in practices and policies } \\
\text { - No standardized CHG dilution methods } \\
\text { - Lack of support to implement new practices }\end{array}$ \\
\hline $\begin{array}{l}\text { Laboratory testing and antimicrobial } \\
\text { stewardship }\end{array}$ & $\begin{array}{l}\text { - Belief that antibiotics are always } \\
\text { helpful } \\
\text { - Variation in insurance coverage for } \\
\text { therapies } \\
\text { - Not discussing therapeutic choices } \\
\text { with providers } \\
\text { - Lack of education and/or } \\
\text { understanding about antibiotic } \\
\text { reason, use (ie, frequency and } \\
\text { duration), and side effects } \\
\text { - Distrust of new therapies }\end{array}$ & $\begin{array}{l}\text { - Overtesting } \\
\text { - Lack of procedures to stop antibiotic course based on test results } \\
\text { - Impacts of patient-reported allergy to prescription (without documented } \\
\text { allergy testing) } \\
\text { - Fear of negative rating from patient for not prescribing an antibiotic } \\
\text { - Inconsistent messaging between providers } \\
\text { - Formulary restrictions } \\
\text { - Limited research and/or education on new evidence-based practices and } \\
\text { alternatives (eg, probiotics) } \\
\text { - Lack of educational outreach in community } \\
\text { - Impact of telemedicine } \\
\text { - Reimbursement policies } \\
\text { - Underusing and/or excluding pharmacists on patient care team } \\
\text { - Antifungals and/or antivirals not included in stewardship } \\
\text { - Lack of standardized scripts for supplies }\end{array}$ \\
\hline
\end{tabular}

Note. HAI, healthcare-associated infections; CHG, chlorhexidine gluconate.

Author for correspondence: Julie Keating, William S. Middleton Veterans Hospital, 2500 Overlook Terrace, Madison, WI, USA 53705. E-mail: julie.keating@va.gov

Cite this article: Keating JA. et al. (2018). Patients as stakeholders: Developing a patient-centered healthcare epidemiology research agenda. Infection Control \& Hospital Epidemiology 2018, 39, 1389-1390. doi: 10.1017/ice.2018.214 that research questions and outcomes are meaningful and relevant to stakeholders, ${ }^{3,4}$ and it may also improve research quality and appropriateness. ${ }^{4-6,9}$ 